\title{
Medicinal plants and their components for wound healing applications
}

\author{
Akshay Sharma', Suryamani Khanna', Gaganjot Kaur ${ }^{2}$ and Inderbir Singh ${ }^{1 *}$
}

\begin{abstract}
Background: Wound is an anatomical and functional disruption of the skin following an injury. In response to the injury, wound healing is a complex process of tissue repair or remodeling. Historically, plants and plant-based constituents have been extensively used for the treatment and management of different types of wounds. In the current times, different types of biopolymers are being researched for developing economical, sustainable, stable, and effective delivery system for the treatment of wounds.

Main text: The present review article attempts to enlist medicinal plants which have been reported to be effective in the treatment of wounds. Plant constituent-based wound dressings have also been discussed systematically including patented formulations reported by different inventors.

Conclusion: The compiled data aims to update the researchers/scientists which will be helpful in providing them a directional view in understanding the role and importance of plant-based components for the treatment and management of wounds.
\end{abstract}

Keywords: Wounds, Medicinal plants, Plant constituents, Delivery systems, Patents

\section{Background}

Medicinal plant materials and herbal remedies derived from them represent a substantial portion of the global medicinal market. Herbal remedies and drugs have played a significant role in curing diseases throughout the history of mankind. Though a large amount of literature is available on their curative properties, standard procedures for quality control of plant materials with respect to their identification (phytochemical, pharmacological, and therapeutic activity) are not available. Standardization of medicinal plants ensure their consistency and therapeutic effectiveness. Herbal products are evaluated for their identity (characterization), quality, and quality of the extracts present, as it is required to evaluate their therapeutic efficacy, i.e., to know their pharmacological action to evidence authenticity [1]. Herbal medicines have the potential to treat and cure illnesses like ulcers, healing of wounds, skin infections inflammation, scabies, leprosy,

\footnotetext{
* Correspondence: inderbir.singh@chitkara.edu.in

${ }^{1}$ Chitkara College of Pharmacy, Chitkara University, Patiala, Punjab, India

Full list of author information is available at the end of the article
}

and venereal disease [2].. Herbal medicines in wound treatment or care include disinfection, debridement, and providing a moist atmosphere which facilitates development of appropriate natural healing climate. Folklore cultures employ a significant number of plants to treat cuts, wounds, and burns $[3,4]$.

A wound is a disruption of living tissue's cellular, anatomical, and functional integrity caused by physical, chemical, electrical, or microbial threats to the tissue [5]. Wound healing is defined as a complex process occurring by regeneration or reconstruction of damaged tissue [6]. The normal response to wound healing is a concerted sequence of events that begins with an injury. When platelets come into contact with exposed collagen, the healing cascade is initiated, causing the accumulation of platelets as well as the release of coagulating factors which in turn result in the formation of a fibrin clot at the injury site. The fibrin clot functions as a temporary matrix which sets the tone for activities that accompany healing [7]. Inflammatory cells, along with the platelets provide essential signals known as cytokines or growth 
factors; also arrive at the injury site [8]. The fibroblast is the connective tissue responsible for collagen deposition that is needed to fix tissue damage. Collagen provides strength, integrity, and structure in normal tissues. Collagen is required to repair the defect and restore anatomical structure and function when tissues are damaged after injury $[9,10]$. If healing does not progress stepwise in the usual way, then it can lead to chronic growth of wounds. Reported patents and articles state that various herbal formulations help accelerate the wound healing process and are useful in its treatment. Medicinal plants such as Curcuma longa (L.), Terminalia arjuna, Centella asiatica, Bidens Pilosa, Aloe barbadensis, and Rauwolfia serpentine have confirmed wound healing activity and are found to be effective in the treatment of wounds.

The review article starts with the classification of wounds followed by various factors affecting the wound healing process along with the mechanism have been explained systematically. Various medicinal plants and their herbal components effective in the management and treatment of wounds have been suitably discussed in text and tabular form. Finally, plant-based dressing and the patented technologies have also been listed.

\section{Main text}

\section{Classification of wounds}

Wounds are generally classified according to the underlying cause of the development of wounds.

\section{Acute wounds}

In acute wounds, there is tissue damage/injury that generally occurs through an orderly and time-reparative phase that results in the anatomical and functional integrity being restored sustainably. Acute wounds are typically caused by the cuts or surgical incisions [11].

\section{Closed wounds}

The blood escapes from the circulatory system in closed wounds but stays inside the body. It becomes evident in the form of bruises.

\section{Open wounds}

Blood leaks from the body through an open wound and bleeding is clearly noticeable. The open wound may be divided further into categories according to the source causing the wound.

\section{Incised wounds}

This is a wound with no loss of tissue and minor damage to tissue. It is caused primarily by sharp objects like a scalpel or knife.

\section{Tear or laceration wounds}

This is the non-chirurgical injury in conjunction with other types of trauma which results in tissue loss and damage.

\section{Puncture wounds}

These are caused by an object which, like a nail or a needle, which punctures the skin. Since dirt may penetrate deep into the wound, chances of infection are common in them.

\section{Abrasive or superficial wounds}

Sliding slip onto a rough surface induces abrasion. During this time, abrasion is scraped off the top layer of the skin, i.e., epidermis which exposes nerve endings resulting in a painful injury.

\section{Penetration wounds}

Penetration wounds are chiefly caused by an object like a knife going in and out of the skin.

\section{Gunshot wounds}

They are typically produced by bullet or similar projectile which drives through or into the body.

\section{Chronic wounds}

Chronic wounds are wounds that have not gone through the usual healing stages and hence reach a state of pathologic inflammation. They need extended healing time [12].

\section{Factors affecting wound healing Oxygenation}

Oxygen is essential for the metabolism of cells, particularly the production of energy through ATP, and is necessary for almost all wound healing processes. It protects wounds from infection, causes angiogenesis, increases differentiation of keratinocytes, migration and re-epithelialization, improves proliferation of fibroblasts and synthesis of collagen, and facilitates contraction of wounds. The microenvironment of the early wound is deprived of oxygen and is very hypoxic owing to ingestion by metabolically active cells. Several systemic disorders will produce reduced vascular flow, including advancing age and diabetes, thereby setting the stage for inadequate oxygenation of the tissue. This superposition of inadequate perfusion produces a hypoxic wound in the sense of recovery. Chronic wounds are hypoxic in particular; tissue oxygen concentrations were measured transcutaneous in chronic wounds of 5 to 20 $\mathrm{mm} \mathrm{Hg}$, relative to control tissue concentrations of 30 to $50 \mathrm{~mm} \mathrm{Hg}$. 


\section{Infections}

Micro-organisms that are typically sequestered on the skin surface gain access to the underlying tissues until the skin is wounded. If the wound is listed as having inflammation, colonization, local invasion/critical colonization, and/or spreading invasive infection determines the state of infection and replication status of the micro-organisms. Contamination is the presence of non-replicating microbes on a wound, while colonization is characterized as the presence without tissue damage of replicating microorganisms on the wound. An intermediate stage is local infection/critical colonization, with proliferation of microorganisms and the beginning of local tissue responses. The involvement of replicating organisms inside a wound with subsequent damage to the host is known as invasive infection. Inflammation is a natural part of the woundhealing process and is necessary for the elimination of micro-organisms that are infected. However, inflammation can be prolonged in the absence of successful decontamination, because microbial clearance is incomplete. The sustained elevation of pro-inflammatory cytokines such as interleukin-1 (IL-1) and TNF-alpha will contribute to both bacteria and endotoxins and elongate the inflammatory process. The wound can reach a chronic state and refuse to heal if this persists. In addition, this prolonged inflammation contributes to an elevated level of matrix metalloproteases (MMPs), a protease family that can degrade the ECM. A decreased level of the naturally occurring protease inhibitors occurs in combination with the increased protease content. This change in protease equilibrium may cause the rapid deterioration of growth factors that occur in chronic wounds.

\section{Age}

The elderly population (people over 60 years of age) is growing more than any other age group (a significant risk factor for delayed wound healing is the World Health Organization and elevated age). Several cellular and molecular-level clinical and animal studies have explored age-related changes and delays in wound healing. It is widely accepted that the impact of aging induces a transient pause in wound healing in stable older people, but not a genuine disability in terms of the consistency of healing.

\section{Stress}

Stress has a considerable influence on human well-being and social behavior. Stress is associated with multiple disorders, such as cardiovascular disease, cancer, compromised wound healing, and diabetes. Several studies have reported that stress-induced neuroendocrine immune equilibrium dysfunction is critical for well-being.

Stressors can contribute to harmful mental conditions, such as depression and anxiety, which can in turn alter physiological mechanisms and/or behavioral behaviors that affect health outcomes. Stressed people are more likely to have risky behaviors, including irregular sleep schedules, insufficient diet, less exercise, and a higher risk for consumption of alcohol, nicotine, and other medications, in addition to the direct effects of anxiety and depression on endocrine and immune function.

\section{Body type}

Body form can also influence the healing of wounds. For instance, an obese patient can experience a compromise in wound healing due to low adipose tissue blood supply. In addition, there is protein malnutrition in some obese patients, which further impedes recovery. Conversely, the absence of oxygen and nutrition stores can interfere with wound healing when a patient is emaciated.

\section{Chronic diseases}

A few of the chronic conditions that can compromise wound healing include coronary heart disease, peripheral vascular disease, stroke, and diabetes mellitus. To have the right plan, patients with chronic illnesses should be monitored closely through their course of care.

\section{Vascular insufficiency}

Various wounds or ulcers-such as arterial, diabetic, pressure, and venous ulcers-can affect the lower extremities. Decreased blood supply is a common cause of these ulcers. The clinician must identify the type of ulcer to ensure appropriate topical and supportive therapies.

\section{Nutrition}

Food has been recognized for more than 100 years as a very significant aspect that impacts wound healing. The most apparent thing is that malnutrition or specific nutritional shortages following trauma and surgery can have a profound impact on wound healing. Special nutrients are also needed in patients with chronic or non-healing wounds and with nutritional deficiencies. The metabolism of energy, carbohydrates, proteins, fats, vitamins, and minerals will all affect the healing process [13].

\section{Mechanism/pathophysiology of wound healing}

Wound healing is a complex mechanism that can be categorized as an allergic response, propagation, and remodeling in three parallel phases. The inflammatory process initiates a proliferative wound repair response further characterized by vascular responses like blood coagulation and hemostasis. Cellular activities include leukocyte infiltration with the release of antimicrobials and cytokines. During the proliferative process, the epithelium is formed to coat the wound surface with the subsequent growth of granulation tissue to fill the 
wound space. The generation of granulation tissue includes fibroblast proliferation, collagen deposition as well as other extracellular matrices, and the development of new blood vessels [14]. The remodeling process begins to restore structural integrity and functional competence to the tissue when the new tissue is established inside the wound. The 3 stages of wound healing, however, are not simple linear procedures, but instead, vary in time. Acute wounds, like burns, other severe injuries, and wounds sustained by surgery, relate to those injuries that heal quickly. An example of a typical acute wound is a neat and uninfected incisional surgical wound approximated by operative sutures. While the desired end product of organized healing is tissue production with similar structure and functions as with retained skin, but regeneration is rare (with significant exceptions, such as early fetal healing). Thus, healing results in an outcome that is structurally and functionally adequate but not equivalent. Wound healing processes tend to be strictly regulated at the wound site by various growth factors and cytokines released. Changes that interfere with regulated timely healing processes increase tissue damage and delay recovery [15].

The different phases (inflammatory phase, proliferative phase, remodeling phase) of wound healing are described in Fig. 1. Blood-borne cells-neutrophils, macrophages, and platelets-play crucial roles during the coagulation and inflammatory phases (A) of the healing. These cells provide the growth factors and interim matrices required for the recruitment into the wound bed of epidermal and dermal cells. The proliferative process (B) starts around 3 days after injury and is characterized by increased rates of proliferation, migration, and extracellular matrix (ECM) synthesis of keratinocytes and fibroblasts in response to autocrine, juxtracrine, and paracrine growth factors. In this process, angiogenesis/neovascularization occurs too. The tissue has a granular texture (granulation tissue), due to the involvement of blood vessels. Eventually, inside the granulation tissue, differentiated fibroblastic cells (myofibroblasts) begin to remodel the extracellular matrix at about 1 to 2 weeks after injury. Extracellular matrix remodeling accompanied by resident cell apoptosis leads to an acellular scar formation [17, 18]. Medicinal plants and their metabolites used in the treatment of different types of wounds are depicted in Table 1.

\section{Traditional use of medicinal plants in wound healing}

For more than 5000 years, Egyptians, indigenous peoples of Africa, Asia, Romans, and the Americas have used medicinal plants as first-line therapy for inflammation, burns, ulcers, and surgical wounds. They contain many natural bioactive compounds that help fasten the process of wound healing and regenerate tissue at the wound site. Some examples of medicinal plants and their wound healing effects are listed below [50].

\section{Centella (Centella asiatica)}

This was also known as Asian pennywort, used to facilitate healing of wounds. To facilitate the healing of the chronic ulcers in terms of their distance, depth, and scale, extracts from the Centella asiatica aerial sections are reported. Asiaticoside isolated from the Centella asiatica has been shown to promote epithelialization and collagen deposition in a punch type wound. Centella asiatica isolated triterpenes improve collagen remodeling and the synthesis of glycosaminoglycans. In addition, it has been shown that oral administration of madecassoside from Centella asiatica promotes collagen synthesis and angiogenesis at the wound site [51].

\section{Turmeric (Curcuma longa)}

Curcumin has been used as a remedy and as a food seasoning for many years, being an active agent found in the Curcuma longa root and a member of the ginger tribe. Curcumin is used by conventional Ayurvedic medicine practitioners to treat asthma, respiratory diseases, liver disorders, diabetes, and skin injury [52]. Curcumin is a popular remedy in traditional Chinese medicine for stomach pain. Curcumin has been commonly used for decades by different ethnic groups and are among the most widely studied nutraceuticals. A highly pleiotropically molecule has been shown to interact at transcription, translation, and post-translation levels with key cellular pathways. Proinflammatory cytokines, apoptosis, NF-yB, cyclooxygenase 2, 5-LOX, STAT3, C-reactive protein, prostaglandin E2, cell adhesion molecules, phosphorylase kinase, $\beta$-transforming growth factor, triglycerides, ET-1, creatinine, heme oxygenase-1, AST, and ALT are found in the goal pathways. Experimental findings from various in vivo trials and in vitro tests show that by altering the pericellular and extracellular matrix, curcumin produces much of its beneficial effects. It may not be surprising, therefore, that curcumin stimulates fibroblast proliferation, the development of granulation tissue and the deposition of collagen in the healing of cutaneous wounds [53].

\section{Bay (Sphagneticola trilobata)}

Plant, Wedelia trilobata, also known as Sphagneticola trilobata, was originally native to the tropical Americas; however, it is now widespread in the tropics as one of the world's most invasive plants. Extracts of alcohol from the Wedelia trilobata leaves have been used to treat rheumatism, persistent wounds and sore arthritic joints. Luteolin, a flavonoid in the leaves, has been shown to contribute to Wedelia trilobata medicinal benefit, conferring neuroprotective, anti-cancer, 

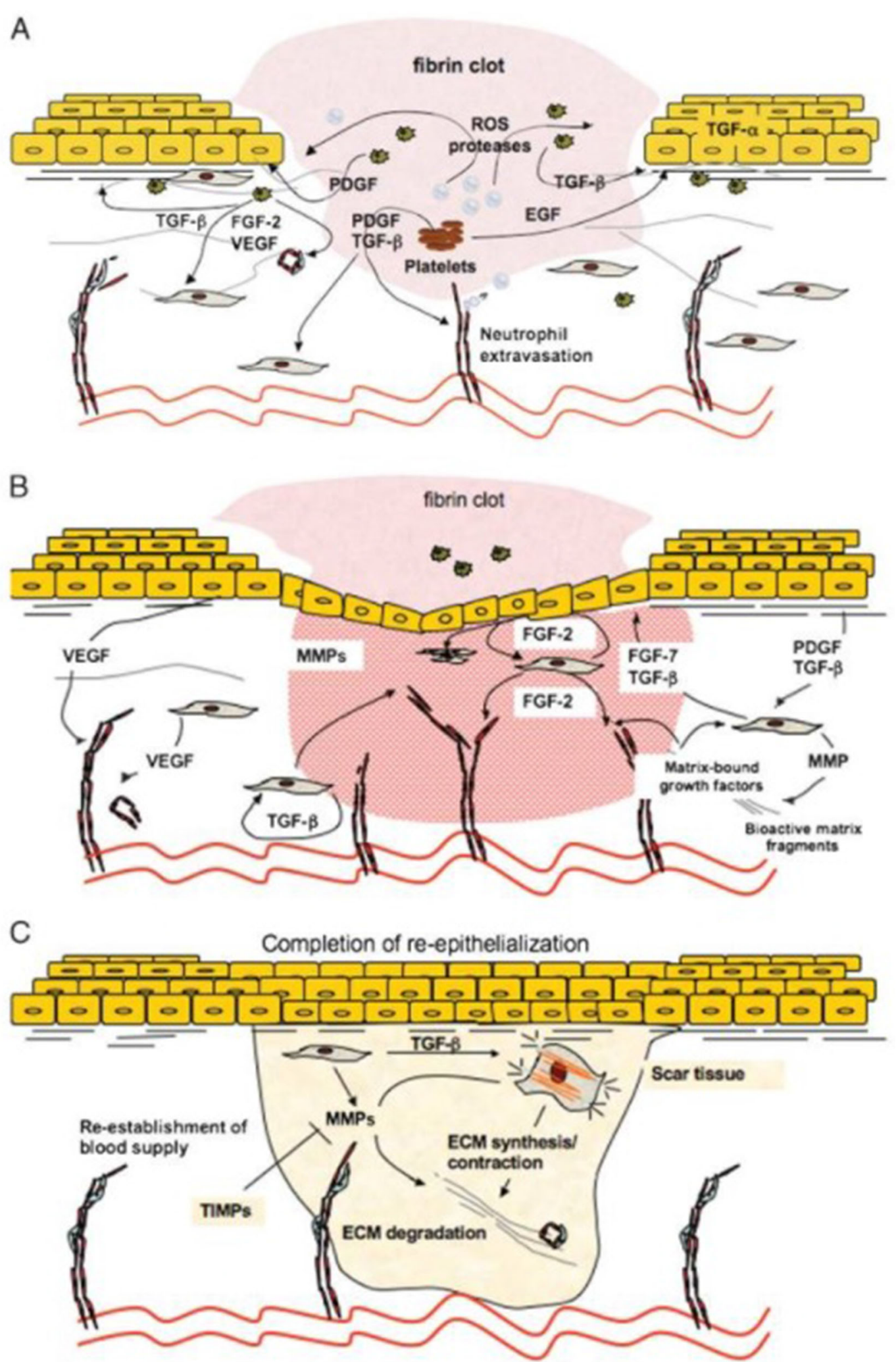

Fig. 1 Different phases of wound healing (adapted from reference [16]) 
Table 1 Medicinal plants and their metabolites used for treating different types of wounds

\begin{tabular}{|c|c|c|c|c|c|}
\hline $\begin{array}{l}\text { S. } \\
\text { no. }\end{array}$ & Medicinal plants & Part used & Metabolites & Uses & Reference \\
\hline 1. & Turmeric (Curcuma longa) & Rhizomes & Curcumin, vitamin A, proteins & $\begin{array}{l}\text { Chronic wound } \\
\text { healing }\end{array}$ & [19] \\
\hline 2. & $\begin{array}{l}\text { Liquorice (Glycyrrhiza } \\
\text { glabra) }\end{array}$ & Roots & Glycyrrhizin, glycyrrhetinic & $\begin{array}{l}\text { Acute/chronic } \\
\text { wound healing }\end{array}$ & [20] \\
\hline 3. & Centella (Centella asiatica) & Leaves & Asiatic acid, asiaticoside madecassoside, madecassic acid & $\begin{array}{l}\text { Incision wound } \\
\text { healing }\end{array}$ & {$[21,22]$} \\
\hline 4. & $\begin{array}{l}\text { Carbonal (Mimosa } \\
\text { tenuiflora) }\end{array}$ & Stem & $\begin{array}{l}\text { Mimosine (an alkaloid), sitosterol, amino acids, linoleic acid, } \\
\text { tannins, polyphenols, and oleic acid }\end{array}$ & $\begin{array}{l}\text { Chronic wound } \\
\text { healing }\end{array}$ & [23] \\
\hline 5. & Honey (Apis mellifera) & $\begin{array}{l}\text { Secretion } \\
\text { from hive }\end{array}$ & $\begin{array}{l}\text { 5-Hydroxyimidacloprid, 4,5-dihydroxyimidacloprid, } \\
\text { desnitroimidacloprid, 6-chloronicotinic acid, olefin }\end{array}$ & $\begin{array}{l}\text { Acute wound } \\
\text { healing }\end{array}$ & [24] \\
\hline 6. & $\begin{array}{l}\text { Theaceae (Camellia } \\
\text { pubipetala) }\end{array}$ & Leaves & Flavonoids, theanine and caffeine & $\begin{array}{l}\text { Excision wound } \\
\text { healing }\end{array}$ & [25] \\
\hline 7. & $\begin{array}{l}\text { Forest Champa } \\
\text { (Spermadictyon } \\
\text { suaveolens) }\end{array}$ & Roots & Triterpenes, sesquiterpenes, alkaloids & $\begin{array}{l}\text { Chronic wound } \\
\text { healing }\end{array}$ & [26] \\
\hline 8. & Neem (Azadirachta indica) & All portions & Azadirachtin, azadirone, nimbin, nimbidin, nimbinin & $\begin{array}{l}\text { Open wound } \\
\text { healing }\end{array}$ & [27] \\
\hline 9. & $\begin{array}{l}\text { Sesame (Sesamum } \\
\text { indicum L.) }\end{array}$ & Seeds & $\begin{array}{l}\text { Metronidazole, E and C vitamins, sesamolinol, sesamol, sesaminol, } \\
\text { sesamolin }\end{array}$ & $\begin{array}{l}\text { Acute/chronic } \\
\text { wound healing }\end{array}$ & [28] \\
\hline 10. & $\begin{array}{l}\text { Trumpet tree (Cecropia } \\
\text { peltata) }\end{array}$ & Leaves & $\begin{array}{l}\text { Flavanoids, terpenes phenols, alkaloids, sterols, waxes, fats, tannins, } \\
\text { gums, resin acids }\end{array}$ & $\begin{array}{l}\text { Closed wound } \\
\text { healing }\end{array}$ & [29] \\
\hline 11. & $\begin{array}{l}\text { Kencur (Kaempferia } \\
\text { galanga) }\end{array}$ & Rhizomes & $\begin{array}{l}\text { Amino acids, protein, carbohydrate, alkaloids, steroids, cholesterol, } \\
\text { cardiac glycosides, }\end{array}$ & $\begin{array}{l}\text { Incision wound } \\
\text { healing }\end{array}$ & [30] \\
\hline 12. & Druce (Prosopis cineraria) & Leaves & $\begin{array}{l}\text { Patulitrin, diketones, spicigerin, } \beta \text {-sitosterol, stigmasterol, hentria- } \\
\text { contane, octasanol, and prosogerin A, B, C, and D }\end{array}$ & $\begin{array}{l}\text { Closed wound } \\
\text { healing }\end{array}$ & [23] \\
\hline 13. & Maidenhair (Ginkgo biloba) & $\begin{array}{l}\text { Leaves and } \\
\text { seeds }\end{array}$ & Flavonoids, lactones, and ginkgolic acid & $\begin{array}{l}\text { Closed wound } \\
\text { healing }\end{array}$ & [31] \\
\hline 14. & $\begin{array}{l}\text { Indian mulberry (Morinda } \\
\text { citrifolia) }\end{array}$ & $\begin{array}{l}\text { Leaves and } \\
\text { fruit }\end{array}$ & Anthraquinones, steroid, phenol, tannin, and terpenoids & $\begin{array}{l}\text { Closed wound } \\
\text { healing }\end{array}$ & [32] \\
\hline 15. & $\begin{array}{l}\text { Club Moss (Lycopodium } \\
\text { serratum) }\end{array}$ & $\begin{array}{l}\text { Spores and } \\
\text { whole fern }\end{array}$ & Alkaloids, steroids, tannins & $\begin{array}{l}\text { Acute/chronic } \\
\text { wound healing }\end{array}$ & [33] \\
\hline 16. & $\begin{array}{l}\text { Madagascar periwinkle } \\
\text { (Catharanthus roseus) }\end{array}$ & Leaves & Monoterpenoids alkaloids, vinblastine, Vincristine & $\begin{array}{l}\text { Acute/chronic } \\
\text { wound healing }\end{array}$ & [34] \\
\hline 17. & $\begin{array}{l}\text { Asthma Weed (Euphorbia } \\
\text { hirta) }\end{array}$ & Leaves & Saponins, tannins, flavonoids, alkaloids, glycosides & $\begin{array}{l}\text { Chronic wound } \\
\text { healing }\end{array}$ & [35] \\
\hline 18. & $\begin{array}{l}\text { Red sandalwood } \\
\text { (Pterocarpus santalinus) }\end{array}$ & Bark wood & $\begin{array}{l}\text { Santalin A and B, savinin, calocedrin, pterolinus } K \text { and } L \text {, and } \\
\text { pterostilbenes }\end{array}$ & $\begin{array}{l}\text { Acute/chronic } \\
\text { wound healing }\end{array}$ & [36] \\
\hline 19. & $\begin{array}{l}\text { Lawsonia alba (Lawsonia } \\
\text { inermis) }\end{array}$ & $\begin{array}{l}\text { Leaves and } \\
\text { roots }\end{array}$ & $\begin{array}{l}\text { Coumarins, naphthoquinone, flavonoids, sterols, triterpene, and } \\
\text { xanthones }\end{array}$ & $\begin{array}{l}\text { Chronic wound } \\
\text { healing }\end{array}$ & [37] \\
\hline 20. & $\begin{array}{l}\text { Jandi or Ghaf (Prosopis } \\
\text { cineraria) }\end{array}$ & $\begin{array}{l}\text { Leaves and } \\
\text { pods }\end{array}$ & $\begin{array}{l}\text { Patulitrin, diketones, spicigerin, } \beta \text {-sitosterol, stigmasterol, hentria- } \\
\text { contane, octasanol, and prosogerin A, B, C, and D }\end{array}$ & $\begin{array}{l}\text { Cutaneous wound } \\
\text { healing }\end{array}$ & [38] \\
\hline 21. & Aloe (Aloe vera) & Leaves & Anthaquinone, $\mathrm{C}$ and $\mathrm{E}$ vitamins, amino acids & $\begin{array}{l}\text { Open wound } \\
\text { healing }\end{array}$ & {$[39,40]$} \\
\hline 22. & $\begin{array}{l}\text { Bay (Sphagneticola } \\
\text { trilobata) }\end{array}$ & Leaves & Flavonoids, terpenoids, alkaloid, and saponin & $\begin{array}{l}\text { Incision wound } \\
\text { healing }\end{array}$ & {$[41,42]$} \\
\hline 23. & Adusa (Adhatoda vasica) & Leaves & Flavonoids, tannins & $\begin{array}{l}\text { Excision wound } \\
\text { healing }\end{array}$ & [43] \\
\hline 24. & $\begin{array}{l}\text { Humble plant (Mimosa } \\
\text { pudica) }\end{array}$ & Whole plant & $\begin{array}{l}\text { Mimosine (an alkaloid), sitosterol, amino acids, linoleic acid, } \\
\text { tannins, polyphenols, and oleic acid }\end{array}$ & $\begin{array}{l}\text { Excision wound } \\
\text { healing }\end{array}$ & [23] \\
\hline 25. & Papaya (Caricapapaya) & Latex, fruit & Papain & $\begin{array}{l}\text { Diabetic, burn, soft } \\
\text { tissue wounds }\end{array}$ & [44] \\
\hline 26. & Jungle flame (Ixora & Roots, leaves & Sesquiterpenes, Triterpenes, geranyl acetate, ursolicacid & Cutaneous, excision & [45] \\
\hline
\end{tabular}


Table 1 Medicinal plants and their metabolites used for treating different types of wounds (Continued)

\begin{tabular}{|c|c|c|c|c|c|}
\hline $\begin{array}{l}\text { S. } \\
\text { no. }\end{array}$ & Medicinal plants & Part used & Metabolites & Uses & Reference \\
\hline 27. & Betle Piper (Piper betle L.) & Leaves & Phenolic complex, betal-phenol, chavicol & $\begin{array}{l}\text { Excision wound } \\
\text { healing }\end{array}$ & [46] \\
\hline 28. & $\begin{array}{l}\text { common wireweed (Sida } \\
\text { acuta) }\end{array}$ & Whole plant & Alkaloids, terpenes, and flavonoids & $\begin{array}{l}\text { Excision, incision } \\
\text { wound healing }\end{array}$ & [47] \\
\hline 29. & $\begin{array}{l}\text { Drumstick tree (Moringa } \\
\text { oleifera) }\end{array}$ & Leaves & Vitamins vicenin-2, beta-carotene, phenolics, amino acid, & $\begin{array}{l}\text { Excision, incision } \\
\text { wound healing }\end{array}$ & [48] \\
\hline 30. & $\begin{array}{l}\text { Indian olive (Olea } \\
\text { europaea) }\end{array}$ & Leaves, oil & Biophenolics, Oleuropein secoiridoid, Luteolin & $\begin{array}{l}\text { Incision wound } \\
\text { healing }\end{array}$ & [49] \\
\hline
\end{tabular}

antioxidant, and immunomodulatory activities. Traditional healers treat skin wounds using the Wedelia trilobata leaves. Luteolin inhibits the expression of NF-kBregulated proinflammatory cytokines, a characteristic feature of skin infection and psoriasis. In a study designed to validate this traditional use, Balekar et al. [54] fractionated ethanolic extracts from the leaves of Wedelia trilobata and assayed them in vitro. Specific subfractions were found to support fibroblast viability, proliferation, and migration. Different subfractions were also found to be active against Staphylococcus aureus and Staphylococcus epidermidis.

\section{Aloe (Aloe vera)}

Aloe vera comprises of many natural bioactive compounds, including basic and complex such as glycosides, polysaccharides, saponins, pyrocatechol, anthraquinones, acemannan, phytol, oleic acid, and water-soluble polysaccharides. Acetone extracts from Aloe vera leaves show greater antimicrobial activity than that of alcohol and aqueous extracts. Aloe vera tends to be more susceptible to gram-positive bacterial species than gram-negative species. Saponins, acemannan, and anthraquinone derivatives are compounds with a proven antimicrobial activity. Acemannan, a large Aloe vera mucopolysaccharide (mesoglycan), is an effective stimulator for the operation of macrophages and $\mathrm{T}$ cells and induces the transcription of proinflammatory mRNAs (including IL-1af, IL-1 $\beta$, IL-6, TNF-af, PGE2, and nitrous oxide). Mesoglycan moieties bind and absorb endogenous mitogenic inhibitors and species of reactive oxygen, which promote phagocytosis. Coincidentally, glycans stabilize, prolonging their function, the secreted cytokines, growth factors, and other bioactives [39, 55]. Topically applied acemannan, acting through cyclin D1 and AKT/mTOR signaling pathways has been documented to significantly reduce the time for wound closure [56].

\section{Burdock (Arctium lappa)}

This, generally referred to as burdock, is a commonly grown perennial weed. Arctium lappa is used in the treatment of sore throats and skin pathologies such as boils, rashes, and acne in North America, Europe, and Asia. In a clinical trial, the antioxidant, antimicrobial, anti-inflammatory, anti-diabetic, antiviral, anti-cancer, and hepatoprotective effects of Arctium lappa were detected. It has been shown that Arctium lappa root extract greatly enhances dermal ECM metabolism, affects glycosaminoglycan turnover and decreases visible in vivo wrinkles in human skin. Arctium lappa has also been reported to control cell adhesion and gene expression in canine dermal fibroblasts, influencing the Wnt/ $\beta$-catenin signaling pathway, known to be a key wound cure regulator. In a pilot study of one medical drug, namely, Arctium lappa, burns and wounds topical ointment (B\&W), discomfort and healing of human first and seconddegree burns was found to be handled more efficiently than the control procedure [57].

\section{Ginseng (Panax ginseng)}

In China, Japan, Korea, and Eastern Siberia, it is one of the most popular medicinal plants consumed. It is also assumed that recollection increases immunity and physical agility and reduces fatigue. Therefore, Panax ginseng is used to cure depression, anxiety, and chronic fatigue disorders. It has been shown that Panax ginseng causes vasodilatation, controls blood lipids, decreases inflammation, and confers antioxidant, anti-cancer, antibacterial, anti-allergic, anti-aging, and immunomodulatory capacity [58]. Panax ginseng comprises many bioactive compounds, of which the most potent active constituent of Panax ginseng is a family of saponins (called ginsenosides by Asian researchers and panaxosides by Russian scientists). Panax ginseng root extracts have been shown to protect the skin from acute UVB irradiation and significantly improve healing following laser burning and excisional wound injury. Studies indicate that extracts of Panax ginseng strengthen keratinocyte migration and induce proliferation and in vitro increase collagen production in human dermal fibroblasts. It has also shown, however, that ginsenoside $\mathrm{Rb} 2$, isolated from Panax ginseng, induces the development of epidermis in raft culture by increasing epidermal growth factor and receptor expression, fibronectin and the receptor, and keratin and 
collagenase I, all of which play vital/critical roles in wound cure [59].

\section{Neem (Azadirachta indica)}

In wound dressing, it was well known as anti-ulcer, antifungal, antibacterial, antiviral, anticancer, and antioxidant. Viji et al. [60] evaluated nitric oxide scavenging activity in RAW 264.7 cell lines. The nitric oxide concentration was found to be $10 \mu \mathrm{g} / \mathrm{mL}$ in wells with collagen integrated with $1000 \mu \mathrm{g} / \mathrm{mL}$ of neem extract in them. The biocomposite film has good anti-inflammatory activity and nitric oxide scavenging activity. In further tests, the authors performed the antioxidant activities and the biocompatibility test using the neem-incorporated collagen film RAW 264.7 cell lines. The integrated collagen films of the neem extract $(400 \mu \mathrm{g} / \mathrm{mL})$ showed an 80 percent increase in the operation of DPPH scavenging and had a cell viability of more than 80 percent via MTT assay. Researchers examined the capacity for electrospinning four different plant extracts, namely, A. Indica, Indigofera aspalathoides, Memecylon edule (ME), PCL for skin tissue engineering, and Myristica andamanica. A cell proliferation test was used to determine the capacity of human dermal fibroblasts (HDFs) to live on nanofibrous scaffolds, and F-actin and collagen staining evaluated the relationship between HDF and scaffolds. The proliferation of HDF on M from the experiments was apprehensible. The PCL integrated by Edule was the lowest of all and was 31 percent higher than PCL nanofibers after 9 days. M. Edule-incorporated PCL had better cell density, and sufficient cell to cell contact was verified by F-stain analysis. Collagen staining showed that the extracellular matrix (ECM) was secreted by the cells in M. Edule-incorporated PCL. M. Edule extract containing nanofibers has also served as a slot for stem cells that supports epidermal differentiation markers found by separating epidermal lines from human adipose derived stem cells (ADSC) [61].

\section{German chamomile (Chamomilla recutita)}

Researchers studied the effect of nanofibrous membranes of electrospun poly caprolactone/polystyrene (PCL/PS) as chamomile-containing active wound dressings. Therapy qualities C. Recutita (L.) Rauschert, a member of the Asteraceae family, is present because of specific phenolics and flavonoids, apigenin, quercetin, patuletin, luteolin, and their glucosides. Apigenin is the rarest flavonoid in chamomile flora and has a remarkable effect on the wound healing process. Studies of antibacterial and antifungal in vitro demonstrated nanofibers' efficacy against microorganisms, Bacteria S. aureuas, and C. Albicans (fungi) with inhibitory zones approximately $7.6 \mathrm{~mm}$ in diameter. MTT assay demonstrated the adhesion of in vitro cells and the viability of mesenchymal stem cells on the nanofibers. The nanofibers, according to the authors with 15 percent chamomile extract, up to $99 \pm 60.5$ percent of the wound could be cured after 14-day post-treatment periods which were confirmed using a rat wound model. This wound examination showed the accretion of reepithelization and collagen in the dermis tissue, and also the absence of necrosis [62]. Different types of dressings loaded with herbal constituents for the treatment/management of wounds are shown in Table 2.

Table 2 Different types of wound dressings for the delivery of plant-based constituents

\begin{tabular}{|c|c|c|c|}
\hline S. no. & Types of dressings & Formulations & Reference \\
\hline 1. & Films & $\begin{array}{l}\text { - Chitosan films containing basic fibroblast growth factor on wound healing } \\
\text { - Gelatin film dressings } \\
\text { - Polyox and carrageenan based composite film dressings containing anti-microbial } \\
\text { and anti-inflammatory drugs } \\
\text { - Biocomposite films of carrageenan/locust bean gum for transdermal delivery of curcumin. }\end{array}$ & {$[63,64]$} \\
\hline 2. & Fibers & $\begin{array}{l}\text { - Mathematical model for collagen fiber } \\
\text { - Micro-nanofibers for wound healing application } \\
\text { - PVA blended nanofiber matrix for wound healing } \\
\text { - Titanium fiber mesh } \\
\text { - Curcumin loaded alginate-gelatin composite fibers } \\
\text { - Biopolymeric, nanopatterned fibrous carriers for wound healing }\end{array}$ & {$[65-67]$} \\
\hline 3. & Hydrogels & $\begin{array}{l}\text { - Alginate based hydrogels } \\
\text { - Glycosaminoglycan hydrogel } \\
\text { - Ag/graphene hydrogel } \\
\text { - Dextran hydrogel }\end{array}$ & [68-70] \\
\hline 4. & Scaffolds & $\begin{array}{l}\text { - Tissue scaffolds for skin wound healing } \\
\text { - Gelatin nano fibers scaffolds } \\
\text { - Dextrin hydrogel scaffolds } \\
\text { - Peptide nano fiber scaffolds } \\
\text { - Fibrin-based scaffolds }\end{array}$ & {$[71,72]$} \\
\hline 5. & Ointment & $\begin{array}{l}\text { - Hypericum perforatum oil-based ointment } \\
\text { - Herbal ointment of leaf extract of Jatropha curcas }\end{array}$ & {$[73,74]$} \\
\hline
\end{tabular}




\section{Patents on herbal formulation for wound healing}

Phillip Roy et al. 2010 [75] patented that honey could be used in dressings. The dressing consists of an alginate fiber sheet with honey completely impregnated into the fiber sheet. As a result, the dressing has porous surfaces and the dressing becomes gel-like when the exudate gets absorbed upon application to the wound. This patent includes 11 claims describing how honey is impregnated into the dressings. It can be used for treating acute as well as chronic wounds.

Michael Koganov et al. 2013 [76] patented "Bioactive compositions from theacea plants for the treatment of wounds and cuts." The invention relates to the bioactive topical formulation containing the bioactive fractions from theacea plants. The bioactive fraction from theacea plants shows anti-inflammatory action on the skin and normalizing skin damage or tissue injury.

Suresh Balkrishna et al. 2013 [77] patented a "Novel herbal composition for the treatment of wound healing." Their innovation includes a new, synergistic, herbal composition as a regenerative medicine consisting of a mixture of therapeutically efficient quantities of extracts obtained as a basis from Curcuma longa, Glycyrrhiza glabara, Hamil tonia suaveolens, Tipha angustifolia, and Azadirachta indica, as well as an optional basis consisting of Pig fatin Sesamum indicum (Til) oil, useful for wound cure care.

Parveen Walia et al. [78] patented a "Multifunctional natural wound healing matrix" which consists of a wound pad made of hydrophilic cotton fabric coated on one side with zwitterionic low molecular weight chitosan and lined with organic-synthesized silver nanoparticles on top. Curcumin particles and tulsi extracts are used to further improve their properties with herbal medicinal principles and to have a synergistic impact with all the ingredients working together to provide better results for healing.

Suresh Balkrishna et al. [79] also patented "A regenerative medicine, the herbal composition for the treatment of wound healing." This herbal composition is a combination of therapeutically effective amounts of extracts obtained from Curcuma longa, Glycyrrhiza glabara, Hamil tonia suaveolens, Tipha angustifolia, and Azadirachta indica, mainly used for the treatment of wounds and wound therapy. This includes 27 claims and 6 drawing sheets shows testing on different wounds. The invention shows novel synergism and effective composition of herbs as a regenerative medicine. This also offers a preparation method for the herbal composition.

Another scientist, Melikoglu et al. [80], patented "Herbal formulation for topical wound treatment" in this interval with new herbal formulas, which have proved beneficial for the topical treatment of skin wounds and oral mucosal wounds. For the preparation, a solution or gel composed of poly hexamethylene biguanide as an anti-microbial agent and poloxamer as an emulsifier and a product includes at least one herbal ingredient (Comfrey Symphytum officinale L. extract and/or Commiphora molmol tincture) with analgesic, antibacterial, antifungal, and anti-inflammatory effects can be used to enhance analgesic, antibacterial, and anti-inflammatory effects. Poly hexamethylene biguanide (PHMB) was used as a protective agent, algaecide, bactericide/bacteriostatic, fungicide/fungistatic, and microbicide/microbiostatic.

Kerri-Anne et al. [81] patented a "Topical herbal formulation" particularly suitable for the treatment of wounds and skin disorders. This comprises of Gotu kola (Centella asiatica), Figwot (scrophularia nodosa), yarrow (Achillea millefolium), Plantago major, and Echinacea purpurea. The formulation has both anti-inflammatory and anti-microbial properties. It was found particularly effective as a synergistic healing agent in the treatment of wounds, prevention of scar formation, and promotion of hair regrowth in the wound area. It was also found suitable for the treatment of general skin disorders in humans including eczema and nappy rash.

Kenneth A. et al. [82] invented and patented "Buckwheat honey and bacitracin wound-healing dressing." The invention has been found efficacious in the treatment of acute and chronic wounds and skin conditions and regeneration of skin and/or dermal tissue in a chronic wound. The product comprises a composition or formulation mixture of buckwheat honey and bacitracin. In one unique embodiment, the composition is gelled. The composition is applied directly to a wound or a patient's skin or is impregnated on gauze or other similar material on a bandage or dressing for application to an exuding or non-exuding acute or chronic wound or skin condition.

Dinesh Upendra et al. [83] patented "Herbal oil formulation for topical use and medicinal applications thereof." The invention includes a herbal oil solution based on Heterophragma roxburghii bark extract, which can be used topically and can be used to manage and repair numerous skin abnormalities and infections, all types of wounds, and other medical problems associated with diminished human and animal blood supply. The topical herbal oil formulation is an important natural curing therapy for different medical conditions such as, but not limited to, diabetic gangrene, dry gangrene, wet gangrene, athlete's foot, burn wounds, diabetic foot ulcer, bedsore, untreated open wounds, snakebite wounds, and cellulite-formed gangrene.

Mikolaj Tomulewicz et al. [84] patented "Herbal preparation for accelerating wounds and skin inflammations healing and its application." The invention involves a medicinal preparation that can be used in the treatment of wounds and skin inflammation. The herbal 
Table 3 Medicinal plant constituent based patented technologies for wound healing applications

S. Patent Title Remarks Reference

no. no.

1. US 7,714, Use of honey in dressings 183 B2

2. US 2013/ Boiactive compositions from theacea plants 0146481 and processes for their production and use A1

3. US 2013/ Novel herbal composition for the treatment 0323337 of wound healing, a regenerative medicine

A1

4. WO 2014/ A multifunctional natural wound healing 147638 Al matrix

5. US 8,709, Herbal composition for the treatment of 509 B2 wound healing, a regenerative medicine

6. EP 2896 Herbal formulation for topical wound $396 \mathrm{~A} 1$ treatment

7. WO 2019/ Buckwheat honey and bacitracin wound078931 Al healing dressing

8. US 2019/ Herbal oil formulation for topical use and 0201474 medicinal applications thereof

A1
Honey of preferred consistency and viscosity is envisaged and will be used in combination with a variety of medicinal and suitable surgical dressings and will be used as a wound healing buffer.

The innovation is based on isolated bioactive compounds comprising theoretical plant bioactive fractions. This procedure is also meant to prevent inflammatory behavior along with shielding a mammal's skin tissue from damage caused by UV light and also normalizing skin disorders.

The present invention based on a novel, synergistic, effective herbal composition as a regenerative medicine comprising combination therapeutically effective amounts of extracts obtained from Curcuma longa, Glycyrrhiza glabara, Hamil tonia suaveolens, Tipha angustifolia and Azadirachta indica, along with optionally comprising Pig fatin Sesamum indicum (Til) oil as a base, useful for the treatment of wound healing and it also discloses a process for preparation of said herbal composition.

This invention relates to a natural wound-healing matrix that is multifunctional.

A wound bed consisting of a hydrophilic cotton cloth is a matrix of the present innovation

Coated on one side with zwitterionic chitosan of low molecular weight and which is embedded on top of the synthesized silver nano particles. The fragments of curcumin and tulsi are extracts used with herbal medicinal values to further develop their properties and to have herbal medicinal values along with synergistic influence in order to have healthier curing effects for all the ingredients working together.

This invention reveals a novel as well as Synergistic along with effective herbal composition as a regenerative medicine which comprising combination of therapeutically effective amounts of extracts obtained from Curcuma longa, Glycyrrhiza glabara, Hamil tonia suaveolens, Tipha angustifolia, and Azadirachta indica, along with optionally comprising Pig fatin Sesamum indicum (Til) oil as a base, useful for the treatment of wound healing.

This invention concerns modern herbal formulas, which are particularly useful for topical treatment of skin and oromucosal wounds. Formulations may be either a solution or a gel form consisting of an anti-microbial agent, polyhexamethylene biguanide, and poloxamer amer.

In the shape of an emulsifying agent and product that contains at least one herbal ingredient (Comfrey Symphytum officinale L. extract and/or Commiphora molmol tincture), which has analgesic, antibacterial, antifungal and anti-inflammatory properties to increase the treatment of the wound.

A means of treating acute and chronic wounds and skin disorders and regenerating skin or dermal tissue in a chronic wound is the latest innovation. A synthesis or preparation containing a mixture of buckwheat honey and bacitracin is used in the substance. The composition is gelled in one distinctive encarnation. The composition is applied directly to the wound or skin of the patient or impregnated with gauze or other similar material on the bandage or dressing for application to an acute or chronic wound or skin condition that is exuding or non-exuding.

The present disclosure concerns a formulation of herbal oil based on Heterophragma roxburghii bark extract, which can be applied topically and can be used to treat and cure different skin conditions and diseases, all types of wounds, and other therapeutic conditions associated with decreased human and animal blood flow. For various therapeutic conditions such as, but not limited to, diabetic gangrene, dry gangrene, wet gangrene, athlete's foot, burn wounds, diabetic foot ulcer, bed sore, chronic open wounds, snake bite wounds, and gangrene formed due to cellulitis, the disclosed topical herbal oil formulation provides an inexpensive alternative healing therapy. 
preparation is distinguished by the fact that the preparation includes emulsified or suspended Melittis melissophyllum L. organic medium extract. Ten percent to $40 \%$ $\mathrm{w} / \mathrm{w}$ and $\%$ to $20 \% \mathrm{w} / \mathrm{w}$ ethyl alcohol. Vaseline album was used as an organic medium in the case of an ointment from $40 \%$ to $70 \% \mathrm{w} / \mathrm{w}, 2 \% \mathrm{w} / \mathrm{w}$ triethylamine $2 \%$ $\mathrm{w} / \mathrm{w}$, hydroxy cellulose $1 \% \mathrm{w} / \mathrm{w}$ and filtered water, aqua purificata, from $30 \%$ to $35 \% \mathrm{w} / \mathrm{w}$.

Milind Omkar et al. [85] patented "Wakeri (Wagatea spicata Dalzell) for wound healing." The invention comprises Wakeri-fortified Kampillakadi Tailam/oil. The Wakeri fortification comprises oil extract of root bark powder of Wakeri being a component in the Kampillakadi oil. Kampillakadi oil being a medicinal oil comprising oil extract of Vavding, Kutaj, Kapilla, Trifala, Patolpatra, Bala, Nimsal, Lodhra, Nagarmotha, Charolya, Khadirsal, Dhayatiphul, Agaru, and Chandanadded with Sarjaras. The invention also includes a composition comprising Wakeri-fortified Kampillakadi oil for topical application; the compositions comprise (a) a tulle, (b) an ointment, (c) a liniment, (d) a capsule, (e) a wound healing spray, (f) a cream, and (g) a gel. The invention pertains to wound healing properties of Wakeri (Wagatea spicata Dalzell) Wight synonym of Moullava spicata (Dalzell Nicolson) with Kampillakadi Tailam (CHARAK SAMHITA CHIKITSA STHANAM). Table 3 enlists various plant constituent based patented technologies for wound healing applications.

\section{Conclusion}

Wound healing from ancient times remains a challenging clinical issue for effective wound treatment. Wound healing involves multiple populations of cells, the extracellular matrix and the action of soluble mediators like growth factors and cytokines. Much research has been centered on wound care, with emphasis on new therapeutic methods and the advancement of acute and chronic wound treatment techniques in Ayurveda (herbal). New formulas, dressings, and medicinal plant composition are being explored by researchers for developing cost effective, efficient, stable, and sustainable delivery system for the management/treatment of wounds. With the advent of nanotechnology and availability of novel materials, wound management is becoming more effective and patient-centric. Newer technologies like 3D printing are also providing advantageous options for developing different drug delivery systems for managing wounds. Tissue engineering and regenerative medicines are the futuristic view of technologies for developing wound healing systems. Better quality control techniques for identification, screening, and quantification herbal components along with well-designed pre-clinical and clinical studies will open new research gateways in wound care management.

\section{Abbreviations}

ADSC: Adipose-derived stem cells; DPPH: Diphenyl picrylhydrazyl:

ECM: Extracellular matrix; HDF: Human dermal fibroblasts; IL: Interleukins; MTT: 3-(4,5 Dimethylthiazol-2-yl)-2,5-diphenyl tetrazolium; NF-kB: Nuclear factor kappa light chain enhancer of activated B cells; PCL: Polycaprolactone; PGE: Prostaglandins; PS: Polystyrene; TNF: Tumor necrosis factor

\section{Acknowledgements \\ The authors warmly acknowledge support and facilities provided by Chitkara College of Pharmacy, Chitkara University, Punjab, India.}

\section{Authors' contributions}

AS: Data collection and analysis, manuscript writing. SK: Manuscript writing, editing, coordination. GK: Supervision, manuscript editing. IB: Manuscript structure, conceptualization, administration, supervision. All authors have read and approved the manuscript.

\section{Funding}

Not applicable

Availability of data and materials

Not applicable

Ethics approval and consent to participate

Not applicable

Consent for publication

Not applicable

Competing interests

Not applicable

\section{Author details \\ ${ }^{1}$ Chitkara College of Pharmacy, Chitkara University, Patiala, Punjab, India. ${ }^{2}$ Chitkara Business School, Chitkara University, Patiala, Punjab, India.}

Received: 26 November 2020 Accepted: 8 February 2021

Published online: 25 February 2021

\section{References}

1. Mukherjee K, Rajesh Kumar M (2003) Evaluation of wound healing activity of some herbal formulations Published online in Wiley. Inter Sci 117:265-268. https://doi.org/10.1002/ptr.93

2. Kirtikar KR, Basu BD (2001) Indian medicinal plants, Int Plants. Oriental Enterprises, Dehra Dun

3. Budovsky A, Yarmolinsky L, Ben-Shabat S (2015) Effect of medicinal plants on wound healing. Wound Repair Regen 23:171-183

4. Yuan $\mathrm{H}, \mathrm{Ma}$ Q, Ye L, Piao G (2016) The traditional medicine and modern medicine from natural products. Mol 21(5):559

5. Schilling JA (1985) Wound healing. Psyrev 48(2):374-415

6. Flanagan M (1996) Wound management New York. Churc Liv Inc 1:22-26

7. Clark RA (2001) Fibrin and wound healing. Ann N Y Acad Sci 936:355-367

8. Lawrence WT, Diegelmann RF (1994) Growth factors in wound healing. Clin Derm 12(1):157-169

9. Ross R (1969) Wound healing. Sci Am 220(6):40-50

10. Prockop DJ, Kivirikko KI (1995) Collagens: molecular biology, diseases and potentials for therapy. Annu Rev Biochem 64:403-434

11. Schultz GS (1999) Molecular regulation of wound healing in: acute and chronic wounds: nur mngmt. Br, RA (Ed), 2nd edn, pp 413-429

12. Nagori BP, Salonki R (2011) Role of medicinal in wound healing. Res J Med Plant 5(4):392-405

13. Guo S, Dipietro LA (2010) Factors affecting wound healing. J Dent Res. 89(3):219-229

14. Chen J, MD KR (2007) Pathophysiology of acute wound healing. Clin Derm 25:9-18

15. Kirsner RS, Eaglstein WH (1993) The wound healing process. Clin Derm 11: $629-640$

16. Demidova-Rice TN (2012) Acute and impaired wound healing: pathophysiology and current methods for drug delivery. Part 1: Normal and Chronic Wounds: Biology Causes and Approaches to Care. Adv Skin Wound Care 25(7):304-314 
17. Eming SA, Krieg T, Davidson JM (2007) Inflammation in wound repair: molecular and cellular mechanisms. J Invt Derm 127:514-525

18. Humar R, Kiefer FN, Berns H, Resink TJ, Battegay EJ (2002) Hypoxia enhances vascular cell proliferation and angiogenesis in vitro via rapamycin (mTOR)dependent signaling. FASEB J 16:771-780

19. Jain S, Shrivastave S, Nayak S (2007) Recent trends in Curcuma longa Linn. Ph Cog Rev 1:119

20. Ameri A, Rajive BB, Vaidya JG, Apte K, Deokule SS (2013) Anti-staphylococcal and wound healing activities of Ganoderma praelongum and Glycyrrhiza glabra formulation in mice. Int J Appl Res Natural Prod 6(1):27-31

21. Shukla A, Rasik AM, Jain GK, Shankar R, Kulshrestha DK, Dhawan BN (1999) In vitro and in vivo wound healing activity of asiaticoside isolated from Centella asiatica. J Ethnopharmacol 65(1):1-11

22. Chen YJ, Dai YS, Chen BF (1999) The effect of tetrandrine and extracts of Centella asiatica on acute radiation dermatitis in rats. Biol Pharm Bull 22(7): 703-706

23. Kumarasamyraja D, Jeganathan NS, Manavalan RA (2012) Review on medicinal plants with potential wound healing activity. J Pharm Sci 2(4): 105-111

24. Georgescu M, Chifiriuc CM, Marutesc L (2017) Bioactive wound dressings for the management of chronic wounds. Curr Org Chem 21:53-63

25. Yang CS, Chen G, Wu Q (2014) Recent scientific studies of a traditional Chinese medicine tea on prevention of chronic diseases. J Tradit Complement Med 4(1):17-23

26. Rani S, Amanjot G, Surya P, Kanwar K, Kaur S (2016) Wound healing potential of medicinal plants with their screening models: a comprehensive review. J Drug Deliv Ther 6(1):56-56

27. Osunwokeemek O, Allison J, Theodore AO, Julius C (2013) The wound healing effects of aqueous leave extracts of Azadirachta indica on Wistar rats. Int J Nat Res 3:181-186

28. Kiran K, Asad M (2008) Wound healing activity of Sesamum indicum $L$ seed and oil in rats. Indian J Exp Biol 46(11):777-782

29. Sapna S, Anju D, Sanju NS (2016) Traditional Indian medicinal plants with potential wound healing activity: a review. Int J Pharm Sci Res 7(5):1809-1819

30. Himesh S, Singhai AK (2012) A recent update of botanical for wound healing activity. Res J Pharm 3(7):1-7

31. Muhammad AA, Karthivashan G, Arulselvan P, Fakurazi S (2015) In vitro antioxidant properties of bioactive fraction of Moringa oleifera. J Natprod. Biomed Res 1(2):51-56

32. Nayak BS, Isito GN, Maxwell A, Bhogadi V, Ramdath DD (2007) Wound healing activity of Morinda citrifolia fruit juice on diabetes induced rats. J Wound Care 16(2):83-86

33. Manjunatha K, Vidya V, Mankani S, Manohara Y (2007) Wound healing activity of Lycopodium serratum. Indian J Pharm Sci 69(2):283-287

34. Nayak BS, Pinto Pereira LM (2006) Catharanthus roseus flower extract has wound healing activity in Sprague Dawley rats. BMC Comp Alt Med 6(41):1-6

35. Mittal A, Sardana S, Pandey A (2013) Herbal boon for wounds. Int J Pharm Sci 5(2):1-12

36. Yogesh SG, Jeyabalan RSA (2013) Potential wound healing agents from medicinal plants: a review. Pharmacol 4(5):349-358

37. Chaudhary G, Goya S, Poonia P (2010) Lawsonia inermis Linnaeus: a phytopharmacological review. Int J Pharm Sci Drug Res 2(2):91-98

38. Asif A, Kakub G, Mehmood S, Khunum R, Gulfraz M (2007) Wound healing activity of root extracts of Berberis lyceum Royle in rats. Phytother Res 21(6): 589-591

39. Galehdari H, Negahdari S, Kesmati M, Rezaie A, Shariati G (2016) Effect of the herbal mixture composed of Aloe vera Henna Adiantum capillus-veneris and Myrrha on wound healing in streptozotocin-induced diabetic rats. BMC Comp Alt Med 16(1):386

40. Orue G, Gainza G, Gutierrez FB (2017) Novel nanofibrous dressings containing rhEGF and Aloe vera for wound healing applications. Int J Pharma 523(2):556-566

41. Balekar N, Nakpheng T, Katkam NG, Srichana T (2012) Wound healing activity of ent-kaura-9(11)16-dien-19-oicacid isolated from Wedelia trilobata (L.) leaves. Phytomed 19(13):1178-1184

42. Govindappa M (2011) Antimicrobial, antioxidant and in vivo antiinflammatory activity of ethanol extract and active phytochemical screening of Wedelia trilobata (L.) Hitchc. J Med Plants Res 5(24):5718-5729

43. Vinothapooshan G, Sundar K (2010) Wound healing effect of various extracts of Adhatoda vasica. Int J Pharma Bio Sci 1(4):530-536
44. Mahmood A, Salmah I (2005) Wound healing activity of Carica papaya L. aqueous leaf extract in rats. Int J Mol Med 1(4):398-401

45. Selvaraj N, Lakshmanan B, Mazumder PM, Karuppasamy M, Jena SS, Pattnaik AK (2011) Evaluation of wound healing and antimicrobial potentials of Ixora coccinea root extract. Asian Pac J Trop Med 4(12):959-963

46. Le Thi L, Tho NT, Ha DM, Hang PL, Nghia PT, Thang ND (2015) Influence of phytochemicals in Piper betle Linn leaf extract on wound healing. Burns Trauma 3:s41038-015-0023-7

47. Akilandeswari S, Senthamarai R, Valarmathi R, Prema S (2010) Wound healing activity of Sida acuta in rats. Int J Pharmtech Res 2(1):585-587

48. Muhammad AA, Pauzi NAS, Arulselvan P, Fakurazi S (2013) In vitro wound healing potential and identification of bioactive compounds from Moringa oleifera Lam. Biomed Res Int 974580

49. Koca U, Süntar I, Akkol E, Yilmazer D, Alper M (2011) Wound repair potentia of Olea europaea $\mathrm{L}$. leaf extracts revealed by in vivo experimental models and comparative evaluation of the extracts' antioxidant activity. J Med Food 14(1-2):140-146

50. Nair RV (1995) Indian medicinal plants- a compendium of 500 species. (Mentha arvensis Linn, Warrier PK, Nambiar VPK, Ramankutty C editors). Hyd: Ori Long Pvt Ltd 4:15-17

51. Kishore B, Siva Prasad M, Murthy GK (2011) Comparison of the dermal wound healing of Centella asiatica extract impregnated collagen and crosslinked collagen scaffolds. J Chem Pharm Res 3(3):353-362

52. Saraswathy N, Rohit R, Shanmugan K, Charanya S, Ramalingam P (2012) A preliminary investigation of turmeric-agar composite films as bioactive wound dressing material on excision wound on rat model. IJNPR 3(2):237-241

53. Gopinath D, Rafiuddin A, Gomathi M, Chitra K, Sehgal PK, Jayakumar R (2004) Dermal wound healing processes with curcumin incorporated collagen films. Biomaterials 25(10):1911-1917

54. Jain SJ, Tiwari N, Balekar A, Jain DK (2009) Simple evaluation of wound healing activity of polyherbal formulation of roots of Ageratum conyzoides Linn. Asian J Res Chem 2(2):135-138

55. Seongwon C, Myung-Hee C (2003) A review on the relationship between Aloe vera components and their biologic effects. Sem Int Med 1(1):53-62

56. Ahmad O, Aboutorab TN, Naeini T, Behrooz NE (2010) Effect of aqueous extract of aloe vera on experimental cutaneous wound healing in rat. Vet Arhiv 80(4):509-522

57. Ramnath V, Sekar S, Sankar S, Sastry TP, Mandal AB (2012) In vivo evaluation of composite wound dressing material containing soya protein and sago starch. Int J Pharm Sci 4(2):414-419

58. Xiong Y, Chen L, Man J, Hu Y, Cui X (2019) Chemical and bioactive comparison of Panax notoginseng root and rhizome in raw and steamed forms. J Gin Res 43(3):385-393

59. Lee J, Hwang H, Ko EJ (2014) Immunomodulatory activity of red ginseng against influenza A virus infection. Nutrients 6(2):517-529

60. Viji CS, Trikkurmadom SA, Rajalekshmi G, Pandimadevi M (2015) Preliminary in vitro study on the bovine collagen film incorporated with Azadirachta indica plant extract as a potential wound dressing material. Int J PharmTech Res 8(6):248-257

61. Viji CS, Trikkurmadom SA, Rajalekshmi G, Pandimadevi M (2015) Collagen Azadirachta indica (neem) leaves extract hybrid film as a novel wound dressing: in vitro studies. Int J Pharm Sci Rev Res 32(2):193-199

62. Behrooz M, Payam Z, Iraj R, Morvarid M, Abdolghaffari HA, Mohammad AZ (2013) Morphology drug release, antibacterial, cell proliferation and histology studies of chamomile-loaded wound dressing mats based on electrospun nanofibrous poly(e-caprolactone)/polystyrene blends. J Biomed Mater Res Part B 102(5):977-987

63. van Rijswijk L (2006) Ingredient-based wound dressing classification: a paradigm shift that is passe and in need of replacement. J Wound Care 15:11-14

64. Sharma A, Singh I, Puri V (2019) Preparation and characterization of biocomposite films of carrageenan/locust bean gum/montmorrillonite for transdermal delivery of curcumin. Bioimpacts 9(1):37-43

65. Waring MJ, Parsons D (2001) Physico-chemical characterisation of carboxymethylated spun cellulose fibers. Biomaterials 22:903-912

66. Sharma A, Mittal A, Puri V, Singh I (2020) Curcumin-loaded, alginate-gelatin composite fibres for wound healing applications. 3 Biotech 10:464

67. Sharma A, Puri V, Kumar P, Singh I (2020) Biopolymeric, nanopatterned, fibrous carriers for wound healing applications. Curr Pharma Des 26(38): 4894-4908(15)

68. Hoffman AS (2002) Hydrogels for biomedical applications. Adv Drug Deliv Rev 43:3-12 
69. Kuo CK, Ma PX (2001) lonically crosslinked alginate hydrogels as scaffolds for tissue engineering Part 1. Structure gelation rate and mechanical properties. Biomaterials 22:511-521

70. Wang L, Shelton RM, Cooper PR, Lawson M, Triffitt JT, Barralet JE (2003) Evaluation of sodium alginate for bone marrow cell tissue engineering. Biomaterials 24:3475-3481

71. Whitaker MJ, Quirk RA, Howdle RA, Shakesheff KM (2001) Growth factor release from tissue engineering scaffolds. J Pharm Pharmacol 53:1427-1437

72. Storie H, Mooney DJ (2006) Sustained delivery of plasmid DNA from polymeric scaffolds for tissue engineering. Adv Drug Deliv Rev 58:500-514

73. Didem D (2020) Development of Hypericum perforatum oil incorporated antimicrobial and antioxidant chitosan cryogel as a wound dressing material. Int J Bio Macro 161:1581-1590

74. Esimone CO, Nworu CS (2008) Cutaneous wound healing activity of a herbal ointment containing the leaf extract of Jatropha curcas L. (Euphorbiaceae). Int J App Res Nat Prod 1(4):1-4

75. Caskey PR (2010) Api-med Medical Honey Limited. Use of honey in dressings. US 7,714,183 B2 2010

76. Akzo Nobel surface chemistry. Michael Koganov (2013) Bioactive compositions from thecae plants and processes for their production and use. US 2013/0146481 A1 2013

77. Suresh Balkrishna Patankar (2013) Novel herbal composition for the treatment of wound healing a regenerative medicine. US 2013/0323337 A1 2013

78. Walia, praveen, Walia, amita (2014) A multifunctional natural wound healing matrix. WO 2014/147638 Al 2014

79. Patankar SB (2014) Herbal composition for the treatment of wound healing. A regenerative medicine. US 8,709,509 B2 2014

80. Melikoglu, Ahmet (2015) EP 2896396 A1 2015

81. Kerri-Anne carlene weller, Co. Mayo (2017). A topical herbal formulation. GB 2543091 A1 2017

82. Sabacinski KA (2019) Buckwheat honey and bacitracin wound-healing dressing. WO 2019/078931 Al 2019

83. Dinesh Upendra Nayak, Rabindranath AITHAL, Dakshin Kannada (2019) Herbal oil formulation for topical use and medicinal applications thereof. US 2019/0201474 A1 2019

84. Mikolaj Tomulewicz (2019) Herbal preparation for accelerating wounds and skin inflammations healing and its application. US 10,213,469 B2 2019

85. Omkar M (2020) Wakeri for wound healing. WO 2020/044368 A1 2020

\section{Publisher's Note}

Springer Nature remains neutral with regard to jurisdictional claims in published maps and institutional affiliations.

\section{Submit your manuscript to a SpringerOpen ${ }^{\circ}$ journal and benefit from:}

- Convenient online submission

- Rigorous peer review

- Open access: articles freely available online

- High visibility within the field

- Retaining the copyright to your article

Submit your next manuscript at $\boldsymbol{\nabla}$ springeropen.com 